\title{
Arrangement and Performance of On-Site Tax Auditing in the Russian Federation
}

\author{
Salmina S.V. \\ Khafizova A.R. \\ Salmin I.V.
}

Kazan Federal University, Institute of Management, Economics and Finance, Kazan, 420008, Russia

Emails: svetasv21@yandex.ru

Doi:10.5901/mjss.2015.v6n3p732

Abstract

This paper covers the pressing challenges of the on-site tax auditing in the Russian Federation. Although the number of the onsite tax inspections is currently being reduced in Russia, it does not affect their performance efficiency as the tax control authorities select the auditees more thoroughly. We believe that it is a good practice to enhance the performance of the on-site inspections by addition of more criteria to the list of taxpayer selection criteria. This list of criteria may be constantly added for more accurate and effective selection of business units to facilitate further on-site auditing.

Keywords: tax; tax authority; taxpayer; tax audit; on-site tax inspection; tax administration.

\section{Introduction}

So far, the key objective of all countries in the area of taxation policy is to achieve an optimal fiscal performance. The tax administration is aimed to ensure tax returns to the budget system in due time and to the full extent. For the funds being taxes and other obligatory payments to the budget to raise in full, the taxpayers should exactly comply with the tax laws and other regulations. This is precisely why the tax auditing performance is extensively focused now being a primary tax control in the system of tax administration.

\section{Theory}

Assessment of tax authority performance primarily requires determining the definition of tax control performance. The tax control performance means a relationship between tax control objectives and effects. The result of inspections is additional tax charges, dues, fees and fines, however, the additional charges should be legally acceptable while the penalties should be applied correctly.

The first thing to be done for the on-site inspections is thorough selection of the auditees using public criteria of the independent risk evaluation for the taxpayers, which are employed by tax authorities for such selection. The necessity to study these criteria is caused by using extra criteria for more accurate screening of taxpayers subjected to on-site tax auditing. It is obvious that not all the criteria are effective for taxpayers screening. Such criterion as recognition of significant tax deductions in accounts over a defined period (37\%) is mostly used. Then the tax burden of the taxpayer (31\%) follows it, which is below the mean business unit level for a particular industry. If the data of any company differ from industry average values, such company will enter the risk group. However, the industry average offset does not always mean understatement of tax base and attempts to evade the payment of taxes. The reasons of industry average offset may lie within the business profile and facility retrofit. Therefore, these criteria are not always indicative of the taxpayer's negligence. The result is insufficiency of criteria for an effective selection of taxpayers for planning an on-site tax auditing campaign. The tax authorities should be assessed for their performance at the stage of on-site tax auditing in order to analyse the taxpayer selection procedure.

It should be noted that the taxpayer selection procedure and the relation between the tax authorities and the taxpayers in general are covered by Alm J., Cherry T., Jones M., McKee M, [1], [2], Li D., He Y., Xu Y., Fan Y. [3], Rusdi Hidayat N., Suhadak, Darminto, Handayani S. R., Otok B. W. [4], Hauptman L., Horvat M., Korez-Vide R. [5], Tay, A.S.M. [6]. Crokidakis N. [7] examine the evasion of the taxes. Tan F., Yim A. [8], Hauptman L., Horvat M., Korez-Vide R. [9] describe the anti-evasion tools. The international fiscal cooperation is covered by Kudrle, R.T. [10], Orlova M. [11]. 


\section{Results}

The performance of on-site tax auditing conducted by Russian tax authorities over a period from 2011 through 2013 is provided in Table 1.

Table 1. On-site tax inspections in the Russian Federation over 2011-2013

\begin{tabular}{|l|c|c|c|}
\hline Reference & 2011 & 2012 & 2013 \\
\hline Total inspections in Russia & 73844 & 67351 & 39771 \\
\hline Inspections that revealed taxation breaches & 71124 & 66579 & 39316 \\
\hline Total additional charges due to the inspections, thousand Rubles & 287946791 & 311495826 & 279289995 \\
\hline Additional tax charges, thousand Rubles & 214927383 & 236859119 & 210624978 \\
\hline Fines, thousand Rubles & 73019408 & 74636707 & 68665017 \\
\hline Inspections of companies of total number on-site inspections & 51653 & 45083 & 33196 \\
\hline Inspections of companies that revealed taxation breaches & 51081 & 44664 & 32806 \\
\hline Total additional charges (company), thousand Rubles & 271302942 & 300561500 & 270014394 \\
\hline Additional tax charges (company), thousand Rubles & 202825040 & 228838285 & 203814582 \\
\hline
\end{tabular}

As is seen in the Table 1, the number of on-site tax inspections reduces at fast paces. 40 thousand inspections were conducted in 2013, i.e. $54 \%$ of the on-site inspections in 2011 . Therefore, the number of inspections reduced by $46 \%$ for the last two years. The additional tax charges increased in 2012 by 24 trillion Rubles while they amounted in 2013 at 279 trillion Rubles, which was 9 trillion Rubles less than in 2011 and 33 trillion Rubles less than in 2013. It was fully expected as the number of inspections reduced by half. The percentage of additional tax charges was 75\% in 2011, 76\% in 2012 and $75.5 \%$ in 2013.

According to Table 1, the objectives were achieved in 2012. The additional tax charges come up to $74-76 \%$ of the on-site tax inspections, which is $10 \%$ less than of the off-site inspections. In $99 \%$ of the cases, the on-site tax inspections revealed breaches in each of the three years under consideration, which is shown in Fig. 1.

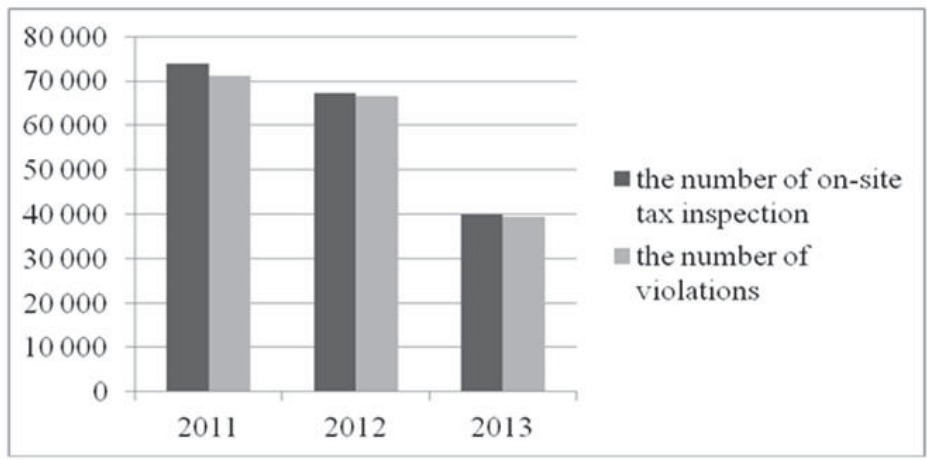

Fig. 1. On-site tax inspections in the Russian Federation over a period of 2011-2013

In 2012, the total number of on-site tax inspections in Russia reduced by 6.5 thousand inspections versus 2011 and amounted 67,351 tax inspections, while their number dropped by $41 \%$ by 2013 to amount 39,771, which was 27.5 thousand inspections less than in 2012 and 34 thousand less than in 2011. In 2013, the percentage of on-site inspections was 53\% of those conducted in 2011 that means effective performance of the tax policy. According to 2013 data, the performance of tax service to screen auditees for inspections comes up to $99 \%$.

The bar chart (Fig. 2) shows how the on-site tax inspections performed in the Volga Federal District grew in 2013 among the total figures. 


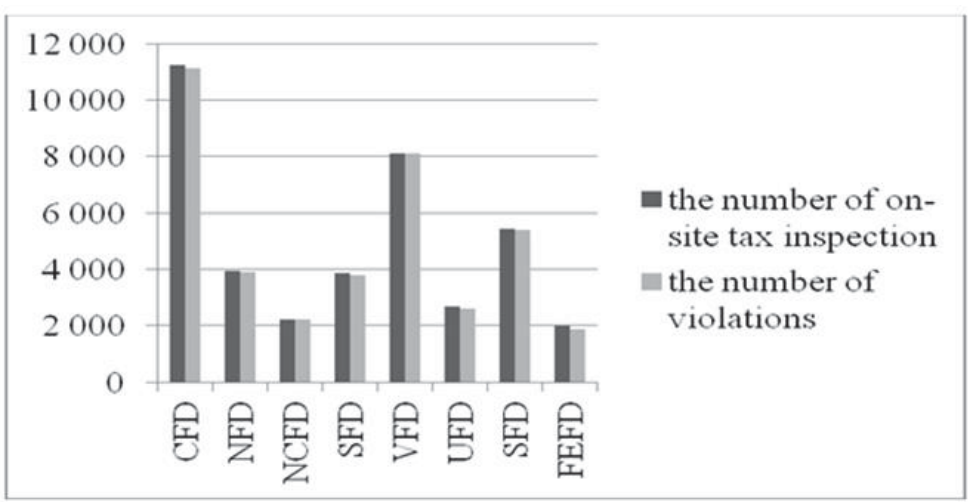

Fig. 2. The number of on-site tax inspections performed in federal districts of Russia in 2013

Thus, 8331 on-site tax inspections were conducted in the Volga Federal District in 2013. Thanks to this, the Volga Federal District occupies the second place among all federal districts of Russia. The Central Federal District heads the list with its 11,184 on-site inspections conducted in 2013. The Siberian Federal District comes third with 4,999 on-site inspections. However, if we look at the positioning of the districts in this analysis in terms of the performance of the onsite inspections, it stands in stark contrast to their number. The North Caucasian Federal District has the lead with 99.7\% performance of on-site inspections. Remaining in an uptrend, the Volga Federal District occupies the second position with $99.4 \%$ performance. With its $99.3 \%$, the Southern Federal District makes the top three. Generally, the lowest performance was recorded in the North-Western Federal District (97.5\%) being a relatively high indicator. It means that the performance efficiency of the on-site tax inspections is up to par, which does not drop below $97.5 \%$.

Therefore, the number of on-site tax inspections is being reduced in Russia; however, it does not lower their performance efficiency, it rather increases, as the tax control authorities more thoroughly select the auditees for tax inspections. It should also be noted that the tax inspections feed the budget completely, which makes them an invaluable and irreplaceable budgeting tool at this stage of civilised society evolution.

\section{Conclusions}

The enhancement of tax administration should integrate both the activities to improve tax authority performance, tax control modes and methods and the measures of screening the auditees for on-site tax auditing. The problem of sustainable selection of taxpayers for test audits is more challenging in the context of large-scale violations of tax laws specific to the current economic growth of Russia. The selection of taxpayers to include into the on-site tax audit schedule requires a reasonable approach. Therefore, the tax offices should put more emphasis on analytical monitoring of financial and economic relations between the related parties considering that the related groups of business units still use different evasion techniques including transfer prices and establishment of profit centres in the areas with lower tax level.

With the variety of market relations, employment of dependence relations becomes one of the most comfortable evasion techniques that fix the deal prices other than market prices. To recognise mutual dependence of the parties, consideration is given to the influence, which may be exerted through participation of one party in the equity of the other one based on the agreement between them or if one party can differently determine the decisions taken by the other party. Such influence should be taken into consideration irrespective of whether one party exercises it alone or together with related parties. Therefore, taxpayers who are the related parties with the large-size taxpayers should be subjected to the tax control in connection therewith. Determination of the aforesaid parties means tax control activities towards both the major taxpayer and its counterparties. Both the legal system and the regulatory bodies surely have an increased focus on this category of taxpayers. However, the suggestion to add the undermentioned criteria to the on-site tax audit planning philosophy is seen as a prerequisite to more accurate selection of taxpayers for on-site tax auditing with the tax administration being enhanced. The following two criteria are proposed to be added:

- Relation of this taxpayer with major taxpayers; and

- Relation of this taxpayer with the economic entity, which revealed severe violations due to on-site tax inspections.

Additional criteria will help improve the taxpayer selection system for on-site auditing the risk-related organisations that may breach the regulations. As the tax authorities are restricted in human and material resources, the tax inspections 
need to be as effective as possible requiring the minimum of efforts and means for their conduction due to selection of such taxpayers that are likely to occur within the list of taxpayers with high capability of tax violations. Using these criteria for screening of taxpayers will update the list of potential auditees that satisfy more criteria.

The economic entity related taxpayers having severe violations are subject to purpose selection, as the probability to reveal tax violations is high owing to relation with unfair taxpayers. Completely new selection principals should be implemented to enhance performance efficiency of test inspections. This will ensure automated selection of taxpayers, enhance the performance of the on-site tax inspections and will make it possible to get off the subjective approach to pick an auditee for auditing.

Additional taxpayer selection criteria would be useful for development of software, which would pick the potential auditees in decreasing order of above-mentioned criteria. The list of criteria may be constantly added for more accurate and effective selection of business units to facilitate further on-site tax auditing.

Perfection of these tax administration areas will improve the Russian tax system. Enhancement of tax administration efficiency is aimed at a balance between rights and obligations of taxpayers and tax authorities, which will also increase the level of a qualitative cooperation between the tax system parties and will have a positive effect on the growth of Russian economic system in general.

\section{References}

Alm J., Cherry T., Jones M., McKee M. Taxpayer information assistance services and tax compliance behavior // Journal of Economic Psychology Volume 31, Issue 4, 2010. pp.577-586.

Alm J., McKee M. Tax compliance as a coordination game // Journal of Economic Behavior and Organization Volume 54, Issue 3, 2004. pp.297-312.

Li D., He Y., Xu Y., Fan Y. Measures of building tax information // Advances in Intelligent and Soft Computing Volume 158AISC, Issue VOL1, 2012. pp.11-15.

Rusdi Hidayat N., Suhadak, Darminto, Handayani S. R., Otok B. W. Measurement model of service quality, regional tax regulations, taxpayer satisfaction level, behavior and compliance using confirmatory factor analysis // World Applied Sciences Journal Volume 29, Issue 1, 2014. pp.56-61.

Hauptman L., Horvat M., Korez-Vide R. Improving tax administration's services as a factor of tax compliance: The case of tax audit // Lex Localis Volume 12, Issue 3., 2014. pp.481-501.

Tay, A.S.M. Technology adoption gone wrong // 15th Americas Conference on Information Systems 2009, AMCIS 2009 Volume 7, 2009. pp.4495-4500.

Crokidakis, N. A three-state kinetic agent-based model to analyze tax evasion dynamics // Physica A: Statistical Mechanics and its Applications Volume 414, 15 November 2014. pp. 321-328.

Tan, F., Yim, A. Can strategic uncertainty help deter tax evasion? An experiment on auditing rules // Journal of Economic Psychology Volume 40, 2014. pp.161-174.

Hauptman L., Horvat M., Korez-Vide R. Improving tax administration's services as a factor of tax compliance: The case of tax audit // Lex Localis Volume 12, Issue 3, 2014. pp.481-501.

Kudrle, R.T. Governing Economic globalization: The pioneering experience of the OECD // Journal of World Trade Volume 46, Issue 3, 2012. pp.695-732.

Orlova M., Khafizova A. The tax component of innovative activity assessment in the Russian Federation // Life Science Journal 2014; 11 (11). pp.328-333.

Sabitova N.M., Jourkina N.S. Assessment of pension coverage in the Russian Federation // Mediterranean Journal of Social Sciences vol. 5 № 24, November 2014, pp. 200-203

Sabitova Nadia, Shavaleyeva Chulpan. Financial risks of constituents of the Russian Federation // Mediterranean Journal of Social Sciences vol. 5 № 24, November 2014, pp. 209-215

Abdreev T.I., Tufetulov A.M. Legal status of an appraiser in the Russian Federation under globalization // Mediterranean Journal of Social Sciences vol. 5 № 24, November 2014, pp. 188-192

Adigamova Farida F., Safiullin Marat A., Tufetulov Aidar M. Mechanism of state tax regulation in the global economy // Mediterranean Journal of Social Sciences vol. 5 № 24, November 2014, pp. 193-199. 